Sournals
INTERNATIONAL JOURNAL OF
ORGANIZATIONAL LEADERSHIP $\begin{gathered}\text { INDUSTRIAL } \\ \text { MANAGEMENT } \\ \text { INSTITUTE }\end{gathered}$

\title{
Code words and covert employment discrimination: Legal analysis and consequences for management
}

\author{
Frank J. Cavico, Bahaudin G. Mujtaba ${ }^{*}$, Marissa Samuel \\ Nova Southeastern University
}

\begin{abstract}
Keywords:

Equal Employment

Opportunity Commission

(EEOC), diversity audits, code words, discrimination.

\section{Received}

05 April 2016

Received in revised form

07 May 2016

Accepted

12 June 2016

Correspondence:

mujtaba@nova.edu

Each organization is likely to have its own unique organizational culture that can either be helpful or hurtful to its employee recruitment, productivity, and retention. Dysfunctional organizational cultures tend to have an informal means of communication where certain code words are used to covertly discriminate toward minorities and candidates based on their appearance, looks, or other demographics. Based on court cases and lawsuits filed, this article provides a review of certain common code words that can be evidence of discrimination in the workplace. These discriminatory remarks, comments, and/or practices might be linked to a person's age, disability, gender, religion, skin color, body size, appearance, and other such dimensions of diversity. The authors provide actual legal examples and show how the courts decided each case and why. The authors also supply concise guidelines and suggestions made by diversity experts, judges, and those who work with the Equal Employment Opportunity Commission (EEOC) on legally impermissible and permissible words and phrases. The article offers recommendations for managers and human resources professionals to conduct regular diversity audits of their organization's culture and overall communication to make sure it represents their mission, vision and value and is free from illegal code words as well as pejorative stereotypical remarks.
\end{abstract}

(C)AIMI Journals

\section{Introduction}

The use of code words as evidence of discrimination was highlighted by a recent case occurring in 2015 wherein the Equal Employment Opportunity Commission (EEOC) brought a civil rights action against the restaurant chain, Texas Roadhouse, alleging age discrimination pursuant to the Age Discrimination and Employment Act of 1967, which prohibits discrimination based on age for people 40 years of age and older (Cavico, Mujtaba \& Samuel, 
2016). The EEOC contends that only $1.9 \%$ of the company's hosts, bartenders, and servers are 40 or older, compared to the nationwide norm of $21 \%$ (Workplace, 2015, p. 24). Some of the code words that the EEOC asserts are evidence of age discrimination on the part of the company are that the company was looking for "young, fun, cute, and bubbly people" and looking for someone that was "young and perky"; and also that the company allegedly told older applicants who were rejected for employment that they "wouldn't fit in” (Workplace, 2015, p. 24). Texas Roadhouse denies the allegations of age discrimination, claiming it has hired thousands of older employees for the aforementioned jobs; and the company, moreover, believes that what the EEOC really wants is quotas, as opposed to hiring the most qualified people for the job (Workplace, 2015, p. 24).

\section{Legal Overview}

Pursuant to U.S. Civil Rights laws, which are enforced by the Equal Employment Opportunity Commission (EEOC), it is illegal to discriminate in employment based on the "protected" categories or characteristics of an employee or job applicant. Protected characteristics encompass a person's race, color, religion, sex, national origin (under Title VII of the Civil Rights Act) as well as a person's age (40 or older) (under the Age Discrimination and Employment Act) and disability (under the Americans with Disabilities Act) (EEOC, Prohibited Employment Policies/Practices, 2015). Civil rights laws forbid discrimination in every aspect of employment, that is, all the "terms and conditions" of employment. "Terms and conditions" encompass hiring and firing, of course, but also promotions, pay, leave, transfers, work assignments, and "breaks". It is also illegal for an employer to base hiring or other job determinations on "stereotypes and assumptions" about a person's race, color, religion, sex, national origin, age, or disability (EEOC, Prohibited Employment Policies/Practices, 2015).

U.S. civil rights laws also prohibit harassment based on the aforementioned protected categories. Harassment is defined by the EEOC as "unwelcome conduct" that is based on race, color, religion, sex, national origin, age, or disability (EEOC, Harassment, 2015). Harassment can be in the form of slurs as well as offensive or derogatory comments or other verbal and physical conduct. Harassing conduct can include offensive jokes, slurs, epithets, or namecalling, as well as threats or physical assaults (EEOC, Harassment, 2015). Moreover, harassment can include ridicule, mockery, insults, "put-downs," as well as offensive objects and pictures. However, the law does not forbid "simple teasing, offhand comments, or isolated incidents," as well as "petty slights and annoyances," unless the incidents are very serious (EEOC, Prohibited Employment Policies/Practices, 2015). Nevertheless, harassment can become illegal if it is so "frequent and severe" that it creates a "hostile or offensive" work environment or if it results in an adverse employment determination. The harassment must create a work environment that the a reasonable person would find "intimidating, hostile, or abusive” (EEOC, Harassment, 2015). The harasser can be the aggrieved employee's immediate supervisor, a supervisor in another area, a co-worker or co-workers, and even someone who is not an employee, such as a customer or client. Moreover, the aggrieved person does not have to be the person harassed but can be any one adversely affected by the offensive conduct (EEOC, Harassment, 2015; EEOC, Prohibited Employment Policies/Practices, 2015). 
Illegal discrimination can take two forms: "disparate treatment," which in essence means intentional purposeful discrimination; and "disparate impact," also called adverse impact, where a presumably neutral employment policy causes a disparate, that is, disproportionate, adverse impact on applicants or employees in a protected category. Code words and phrases come under the purview of "disparate treatment" discrimination. By engaging in disparate treatment the employer is simply treating some employees less favorably than others due to a protected characteristic. Proof of discriminatory intent on the part of the employer is critical in a disparate treatment case. The burden of proof and persuasion is on the plaintiff employee or job applicant who is alleging discrimination. The aggrieved plaintiff job applicant or employee can demonstrate this intent by means of direct or circumstantial evidence. Direct evidence is evidence that clearly and directly reveals the employer's intent to discriminate (Cavico \& Mujtaba, 2014; Mujtaba \& Cavico, 2013; Mujtaba \& Cavico, 2010). An example of direct evidence would be an older worker being told that he or she is "too old," "too tired," and has "bags under the eyes” (Mujtaba \& Cavico, 2010, pp. 47-48). However, vague and factually inadequate allegations, such as that the employee was subject to "numerous discriminatory remarks and harassment," will be insufficient for an employee to establish his or her initial, or prima facie, case (Mujtaba \& Cavico, 2013, p. 9). Speculation and conjecture as to an impermissible animus will also be insufficient (Smith v. Fairview Ridges Hospital, 2010, p. 13).

Nevertheless, since proof of purposeful discriminatory intent is notoriously difficult for an aggrieved plaintiff job applicant or employee to obtain, the courts at times will permit discriminatory motive to be inferred from the facts and circumstances of a particular case. Such a case is called an inferential, circumstantial, or indirect evidentiary case. Code word cases can be based on such inferential evidence. The burden is on the employee or job applicant to establish this initial or prima facie case of inferential discrimination (Cavico \& Mujtaba, 2014; Mujtaba \& Cavico, 2013; Mujtaba \& Cavico, 2010). Moreover, the courts have ruled that this initial burden is not a heavy one; rather, it is "light" and "not onerous" (Mujtaba \& Cavico, 2013, p. 13). To illustrate, in one federal district court case, the employee was asked by his supervisor if he was a Muslim from Pakistan; and when the employee answered in the affirmative, the supervisor stated: "So, you are the one." That statement by the supervisor was deemed to be the principal evidence in the employee establishing his initial case of religious and national origin discrimination (Mujtaba \& Cavico, 2013, p. 13). If the employee does meet his or her burden, and accordingly raises an adequate inference of discriminatory intent on the part of the employer, then the burden shifts to the employer to demonstrate that its job decision in not hiring, not promoting, or discharging the employee was based an appropriate, legitimate, non-discriminatory business reason. However, the aggrieved plaintiff job applicant or employee is then allowed to demonstrate that the employer's proffered and stated reason for the job decision was merely a pretext for intentional discrimination; that is, the reason was fake, phony, a sham, and a lie (Futrell v. J.I. Case, A Tenneco Company, 1994, pp. 345-46; Cavico \& Mujtaba, 2014; Mujtaba \& Cavico, 2013; Mujtaba \& Cavico, 2010). Code word cases can be substantiated by either direct or inferential evidence. The more blatant the code words and phrases are in evidencing discrimination the more likely they will be regarded as direct evidence; whereas the more indirect they are, as well as the more "covert" they are, then 
they likely will be regarded as inferential evidence of discrimination. Since code word cases deal with the issue of discriminatory intent, as well as motive, animus, inference, and pretext, juries are typically required to resolve the critical intent question (Aman v. Cort Furniture Rental Corporation, 1996).

Liability pursuant to civil rights laws also can be based on a work environment that is deemed to be hostile due to harassing conduct based on the protected categories. The courts, however, require that the harassing conduct must be "pervasive and severe" - both subjectively to the aggrieved party and objectively to a "reasonable person" (McGinest v. GTE Service Corp., 2004, p. 1113); but a "reasonable person," it is important to point out, is construed in the position or status of the aggrieved party (Equal Employment Opportunity Commission $v$. Sunbelt Rentals, 2008, p. 315). To further explain, in the context of race, according to one U.S. Court of Appeal, "allegations of a racially hostile work-place must be assessed from the perspective of a reasonable person belonging to the racial or ethnic group of the plaintiff....Racially motivated comments or actions may appear innocent or only mildly offensive to one who is not a member of the targeted group, but in reality be intolerably abusive or threatening when understood from the perspective of a plaintiff who is a member of the targeted group (McGinest v. GTE Service Corp., 2004, p. 1115-16). Subjectivity regarding hostility is measured by the testimony of the aggrieved employee; but objectivity regarding hostility requires additional evidence of offensiveness, pervasiveness, and severity (McGinest v. GTE Service Corp., 2004, p. 1113). Code words and phrases as well as stereotypical remarks can form the basis of this hostile, and thus illegal, work environment. Nonetheless, one federal district court had some cautionary counsel, to wit: "Plaintiffs must clear a high bar in order to satisfy the severe or pervasive test. Workplaces are not always harmonious locales, and even incidents that would objectively give rise to bruised or wounded feelings will not on that account satisfy the severe or pervasive standard. Some rolling with the punches is a fact of workplace life. Thus, complaints premised on nothing more than 'rude treatment by (coworkers),'... ‘callous behavior by (one’s) superiors,'...or 'a routine difference of opinion and personality conflict with (one’s) supervisor'...are not actionable under Title VII (Equal Employment Opportunity Commission v. Sunbelt Rentals, 2008, pp. 315-16).

In the next section of the article, the authors analyze the relevant case law and pertinent Equal Employment Opportunity Commission (EEOC) decisions, guidelines, and pronouncements in order to see exactly what words and phrases rise to the level of discriminatory "code words" as well as words that can establish a hostile work environment. Code words are also called "stereotyped remarks" or "stereotypical remarks" by the courts (Humphries v. City University of New York, 2013, p. 28; Santiago v. State of Connecticut, 2008, p. 17). The EEOC has also used the word "euphemisms" to refer to code words (EEOC, Press Release, 2012). The following case law examination is divided into the one leading U.S. Supreme Court case, cases from the U.S. Courts of Appeals, and federal district court cases.

\section{Legal Analysis, Guidelines, and Pronouncements}

\section{A. The U.S. Supreme Court}

The leading code words case is the U.S. Supreme Court decision in Ash v. Tyson Foods, Inc. (2006). The case is a short one, though very important, as it materially expands the 
interpretation of what constitutes impermissible code words. Actually, the case dealt with one word; thus, it is a code word case. The case arose when two African-American plant supervisors were denied promotions to plant managers. They contended that their rejections were motivated by race discrimination and sued for violations of Title VII. The company defended by saying that the two white applicants who were selected were better qualified. Whereupon, the plaintiff African-American supervisors asserted that the qualifications reason was a fake one, a mere pretext, to cover the true discriminatory motive for the job determinations. The plaintiffs offered as evidence of a discriminatory animus only one word, "boy," which the evidence indicated that the plant manager, who made the disputed decisions, used, referring to the plaintiffs as "boy" "on some occasions" (Ash v. Tyson Foods, Inc., 2006, p. 456). The jury ruled in favor of the plaintiffs; but the federal district court and the Court of Appeals for the $11^{\text {th }}$ Circuit ruled in favor of the defendant company. The reason asserted by the Court of Appeals was that the use of the term "boy," standing alone, could not be evidence of discrimination; the Court of Appeals consequently stated that "modifiers or qualifications" were necessary to be probative of racial bias. The U.S. Supreme Court, however, in an important and expansive decision, disagreed with the Court of Appeals; and accordingly ruled in favor of the plaintiff African-American supervisors. The Supreme Court succinctly explained its reasoning: "Although it is true the disputed word will not always be evidence of racial animus, it does not follow that the term, standing alone, is always benign. The speaker's meaning may depend on various factors including context, inflection, tone of voice, local custom, and historical usage. Insofar as the Court of Appeals held that modifiers or qualifications are necessary in all instances to render the disputed term probative of bias, the court's decision is erroneous" (Ash v. Tyson Foods, Inc., 2006, p. 456). The Supreme Court then remanded the case back to the lower courts for further proceedings consistent with its decision (Ash v. Tyson Foods, Inc., 2006, p. 458).

\section{B. U.S. Courts of Appeals}

In addition to the aforementioned Supreme Court case, there are cases from the U.S. Courts of Appeals that have ruled on code words and phrases. In the Third Circuit Court of Appeals case of Aman v. Cort Furniture Rental Corporation (1996), two black employees, hired as a bookkeeper and credit manager for the district office of a furniture company, claimed they were subjected to a work environment of racial contempt and harassment and discrimination. Evidence indicated that the black employees were referred to as "another one," "one of them," "poor people," "that one," and "all of you." Other statements included "the blacks are against the whites" and "we are going to have to come up there and get rid of all of you." The lower court ruled that these comments were not racially motivated. However, the Court of Appeals disagreed, and ruled as follows: "In our view, however, the use of 'code words' can, under circumstances such as we encounter here, violate Title VII. Indeed, a reasonable jury could conclude that the intent to discriminate is implicit in these comments" (Aman v. Cort Furniture Rental Corporation, 1996, p. 20). The court further explained its rationale: "Statements like the ones allegedly made in this case send a clear message and carry the distinct tone of racial motivation and implications. They could be seen as conveying the message that members of a 
particular race are disfavored and that members of that race are, therefore, not full and equal members of that workplace” (Aman v. Cort Furniture Rental Corporation, 1996, p. 21).

In the Second Circuit Court of Appeals case of Tomassi v. Insignia Financial Group, Inc. (2007), the employee, who was a supervisor of housing complexes, was replaced by an employee 38 years younger because the company purportedly wanted a new, younger clientele. The discharged employee sued for age discrimination. She contended that the supervisor who fired her made, on a continuous basis, several age-related comments, to wit: beginning sentences with "In your day and age...," as well as she "could understand the mentality of" senior residents, she would be "better off retiring," she then could "take some time off to rest," and that she was "well-suited to work with seniors." The district court ruled in favor of the defendant company, basing its decision on two grounds: first, the comments were merely "stray remarks," and second, the comments were not "offensive” (Tomassi v. Insignia Financial Group, Inc., 2007, p. 115). The Court of Appeals, however, overruled the district court, stating that "considering (supervisor's) remarks in the context of all the evidence, they were legally sufficient to sustain a reasonable inference that he was motivated by age discrimination in firing (plaintiff) employee” (Tomassi v. Insignia Financial Group, Inc., 2007, p. 115). As to the "stray remarks" element, the Court of Appeals noted that these comments occurred "every month or so," including at the point of discharge (which gave the comments "more probative" evidentiary value); and thus the remarks were not "stray" ones (Tomassi v. Insignia Financial Group, Inc., 2007, pp. 115-16). And as to the "offensiveness" element, the Court of Appeals stated that "the district court was also mistaken in the view that the probative value of the (supervisor's) "remarks depended on how offensive they were” (Tomassi v. Insignia Financial Group, Inc., 2007, p. 116). The Court of Appeals explained its reasoning: "The relevance of discrimination-related remarks does not depend on their offensiveness, but rather on their tendency to show that the decision-maker was motivated by assumptions or attitudes relating to the protected class. Inoffensive remarks may strongly suggest that discrimination motivated a particular employment action. For example, (defendant supervisor's) assertion to the effect that (plaintiff employee) was well suited to work with seniors was not offensive. Nonetheless, it has a strong tendency in the circumstances to show that (supervisor) believed that, because of (plaintiff employee's) age, she was not suited to deal with the younger tenants (defendant supervisor) was hoping to attract” (Tomassi v. Insignia Financial Group, Inc., 2007, p. 116). Another age discrimination code words case was the Seventh Circuit Court of Appeals decision, Futrell v. J.I. Case, A Tenneco Company (1994), where the employee, a manager and older worker, was discharged for purportedly work-related reasons. The employee argued that those reasons were merely a pretext and the real reason was age discrimination. As such, the employee offered as evidence remarks by upper-level managers that indicated their preference for "youth over age," such as, not a "forward enough thinker," "sharp young people...are delivering a lot of work," and “older people that aren't delivering as much work” (Futrell v. J.I. Case, A Tenneco Company, 1994, p. 347). The appeals court stated that "people often use code words when making discriminatory remarks"; and then ruled that the plaintiff employee had presented sufficient circumstantial evidence that the purported reason for his discharge was a pretext and consequently that he was discharged because of impermissible age discrimination (Futrell v. J.I. Case, A Tenneco Company, 1994, pp. 346-47). 
In the Fifth Circuit Court of Appeals case of Equal Employment Opportunity Commission v. WC \& M Enterprises, Inc., 2007), the employee, from India, sued for national origin and religious harassment based on a series of constant remarks by co-workers, including being called an "Arab," “Taliban,” "Muslim extremist," taking a "militant stance," “This is America," and "just go back where (you) came from.” The district court dismissed the case, ruling that these comments were insufficient evidence to establish the existence of severe and pervasive harassment; but the Court of Appeals disagreed, and thus reversed the decision, stating that "we conclude that the EEOC has presented sufficient evidence to create an issue of fact as to whether the harassment (employee) suffered was so severe or pervasive as to alter a condition of his employment” (Equal Employment Opportunity Commission v. WC \& $M$ Enterprises, Inc., 2007, p. 400). The Court of Appeals also noted that "a single incident of harassment, if sufficiently severe, could give rise to a viable Title VII claim as well as a continuous pattern of much less severe incidents of harassment" (Equal Employment Opportunity Commission v. WC \& M Enterprises, Inc., 2007, p. 400).

In the Ninth Circuit Court of Appeals case of (McGinest v. GTE Service Corp. (2004), the court overruled a district court finding and ruled that the plaintiff employee, an AfricanAmerican, was subject to a hostile work environment based on the use of certain "code words" by co-workers aimed at him, such as "drug dealer," "mammy," "Aunt Jemina," and "biscuit." Yet, what really persuaded the Court of Appeals as to the hostility of the workplace was the fact that the employee's supervisor called him a "stupid $\mathrm{n}^{* * *} \mathrm{r}$ " to his face in front of coworkers (McGinest v. GTE Service Corp., 2004, p. 1116). The Court of Appeals specifically went to great lengths to explain its rationale behind the " $\mathrm{n} * * * \mathrm{r}$ " remark: "It is beyond question that the use of the word ' $n^{* * *} \mathrm{r}$ ' is highly offensive and demeaning, evoking a history of racial violence, brutality, and subordination. The word is 'perhaps the most offensive and inflammatory racial slur in English..., a word expressive of racial hatred and bigotry....The word...is more than a mere offensive utterance.....No word in the English language is as odious or loaded with a terrible history....That the word...is a slur is not debatable....Perhaps no single act can more quickly alter the conditions of employment and create an abusive working environment than the use of an unambiguously racial epithet such as ' $n * * * r$ ' by a supervisor in the presence of his subordinates'” (McGinest v. GTE Service Corp., 2004, p. 1116). The fact that a white worker was also mistreated by the supervisor, which fact was instrumental in the lower court finding for the defendant employer, actually, according to the appeals court, strengthened the African-American employee's case, because the evidence indicated that the white worker was targeted because he made "a friendship across racial lines," and for his acts of "solidarity" with the African-American employee (McGinest v. GTE Service Corp., 2004, p. 1118).

\section{Federal District Court Cases}

In addition to the preceding Courts of Appeals cases, there are several federal district court cases that have ruled on code words and phrases, and which provide further guidance. In Harrison v. Swedish Covenant Hospital (1998), the court ruled that co-workers referring to a black employee as "being from Walgreens" and the "new kid on the block" were neither code words evidencing a hostile racial environment nor expressions of racially derogatory 
stereotypes. The court explained its decision, to wit: "First, the "Walgreens" and "new kid on the block" comments cannot be construed reasonably as racist 'code words.' After all, Plaintiff was, indeed, 'from Walgreens' - she was a cashier prior to her employment with Defendant. The manifest meaning of the comment was discontent with Plaintiff's lack of experience, especially in a health care setting, a point which was made on more than one occasion by members of the staff. Additionally, she was the 'new kid on the block' relative to the employees with whom she was having conflicts, the others having worked together for several years....As the comments were accurate and the non-discriminatory intent of the comments was manifest, the Court finds that a jury could not reasonably regard these statements as racially-charged 'code words'” (Harrison v. Swedish Covenant Hospital, 1998, p. 6). Furthermore, although the language was much more harsh and vile, in the federal district court case of Allen v. Bake-Line Products, Inc. (2001, p. 28), the district court ruled that coworkers referring to African-American employees as "stupid," "lazy," a "mother-f****r," a "b**ch," "and the like" was "not probative of whether a racially hostile work environment existed because these type of statements are not racially motivated." In another federal district court case, supervisors calling a female African-American worker "assertive," “violent," and "insubordinate" did not rise to the level of establishing that the asserted reasons for her discharge - poor performance and insubordination - were merely a pretext for race discrimination (Cuttino v. Genesis Health Ventures, Inc., 2006, p. 16). Moreover, in another federal district court case, co-workers calling a male employee a "loose cannon," "violent," "PTSD," and "intimidating," although called "code words” and "stereotyped remarks" by the court, did not provide a sufficient basis for a reasonable inference that the comments were motivated by discriminatory intent (Santiago v. State of Connecticut, 2008, p. 17). The court explained its rationale: "No discriminatory intent can be inferred from the allegedly stereotypical language plaintiff claims were used against him. First, it is not clear that plaintiff's 'code words' actually refer to stereotypical male characteristics. Women can be violent and intimidating too and suffer from PTSD. Even assuming these words connote male characteristics, plaintiff has not shown that they were directed at him because of his gender" (Santiago v. State of Connecticut, 2008, p. 17). Similarly, in the case of Humphries v. City University of New York (2013), the plaintiff employee, a black woman, an academic program manager and professor was discharged from her university position. She claimed that the discharge was motivated by race and gender discrimination; and as such introduced into evidence that her supervisors and co-workers referred to her as "aggressive," "agitated," "angry,” "belligerent,” “disruptive,” "hands on hip,” "hostile,” "threatening,” and "vituperative," as well as saying she was likened to the "Angry Black Woman Syndrome" (Humphries v. City University of New York, 2013, p. 29). The court, however, although saying that the remarks were "critical," as well as that the employee subjectively believed them to be discriminatory, ruled that the remarks did not, in and of themselves, reveal a discriminatory animus (Humphries v. City University of New York, 2013, p. 29). In the same vein, in the case of Lloyd v. Hon. Eric H. Holder, Jr. (2013), the plaintiff employee, an African-American female was denied a promotion for the asserted reasons of poor work performance and poor performance at the interview. She contended, though, that she was denied the promotion due to racial discrimination, and put forth as evidence a supervisor calling her "lazy, shiftless, and 
incompetent," "ignorant," "inarticulate," and "entitled.” The federal district court sided with the employer, ruling that it had a legitimate, non-discriminatory reason for her discharge and that the words were insufficient for an inferential finding of discriminatory intent (Lloyd $v$. Hon. Eric H. Holder, Jr., 2013, pp. 29-30). The court did indicate that “code words” could evince a discriminatory intent, but also noted that "courts decline to recognize allegations of code words when the words used activate no racial implications or animus" (Lloyd v. Hon. Eric H. Holder, Jr., 2013, pp. 28-29). However, to compare, in the case of Baron v. W.W. Grainger, Inc. (1996), co-workers saying that the plaintiff employee, a Jewish woman, a purchasing manager, lived in "Jewtown" and "you people and your fur coats," and that she was "very vocal," combined with management's lack of a response thereto, was evidence that the asserted reason for firing her - unprofessional conduct - was merely a pretext for the real reason for her discharge - stereotyping her as a "Jewish American Princess" (Baron v. W.W. Grainger, Inc., 1996, pp. 692-93).

\section{Equal Employment Opportunity Decisions and Pronouncements}

The major decision regarding the EEOC and code words will be the aforementioned current agency litigation against the restaurant chain, Texas Roadhouse. Surprisingly, there is not a great deal of information available from the EEOC as to its interpretation of and guidelines for code words. The EEOC's major pronouncement on code words is found in their 2006 Compliance Manual (EEOC, 2006, Compliance Manual, Section 15: Race and Color Discrimination), where the agency states (in the context of race):

Race-related statements include not only slurs and patently biased statements, but also 'code words' that are purportedly neutral on their face but which, in context, convey a racial meaning. The credibility of witness(es) attesting to discriminatory statements, and the credibility of the witness(es) denying them, are critical to determining whether such statements were actually made. If racially discriminatory statements were made, their importance will depend on their egregiousness and how closely they relate - in time and context - to the decisions in question. For example, a statement that there are "too many Asians" in a department, made by a hiring official when discussing applicants, would be strong evidence supporting an AsianAmerican failure-to-hire claim (p. 8).

To further explicate, the EEOC in a 2012 Press Release has indicated that the agency considers the words "overqualified" and "overqualified for this need" as "euphemisms" which are an attempt to "mask age discrimination” (EEOC, Press Release, 2012). The EEOC, regrettably, does not offer any other substantive textual guidance as to code words and their legal import, but the agency does provide some examples and illustrations of improper code words, which will be reported in the forthcoming Code Word Compendium section to this article.

\section{E. Disparate Treatment Code Word Discrimination}


Employers also should be advised to treat employees of different protected classes the same when it comes to the use code of words. Otherwise, the employer risks liability for disparate treatment discrimination. For example, if an employer disciplines a young employee for using a code word that is discriminatory against the elderly, but does not discipline an elderly employee for using the same type of word, the employer risks legal liability for age discrimination. This is especially important for managers to keep in mind because social norms do not always dictate equal treatment when it comes to offensive language. In fact, as one case makes clear, social norms often dictate quite the opposite: that is, a word considered offensive when used by a member of the majority is not so offensive when used by a member of the minority group it has historically been aimed against (Burlington v. News Corp., 2010).

In Burlington, Tom Burlington, a white news anchor, alleged that he was discriminated against based on his race and subject to a hostile work environment when he was terminated after he used the word " $n * * * r$ ". Burlington's claims emerged out of a newsroom editorial meeting that occurred between Burlington and a number of his coworkers. During the meeting, the group discussed a story about the Philadelphia Youth Council of the NAACP having a symbolic burial for the word " $n^{* * *}$." Burlington's colleagues consistently referred to the racial slur as "the n-word" rather than use the full word. However, during the meeting, Burlington asked, "Does this mean we can finally say the word $n^{* * *} r$ ?'" Burlington indicated that he thought that doing so would give the story more credence, and later testified that he "wanted to make the point that I felt if we're going to refer to the word ' $n * * * r$,' we should either say the word ' $n^{* * *} r^{\prime}$ or refer to it as a racial epithet or a slur instead of using the phrase the ' $N$ ' word." Burlington used the word once during the newsroom meeting, and again later on when another meeting was called to discuss his use of the word. A number of employees were bothered by Burlington's language, and Burlington was subsequently suspended and ordered to attend sensitivity training (which he attended). Thereafter, information about Burlington's actions was leaked to the public via a Philadelphia Daily News article. Bad publicity followed, and Burlington was terminated from his job, seemingly as a result of the bad publicity. Yet it appears that Burlington would have been allowed to continue his work had his comments not been leaked to the public (Burlington v. News Corp., 2010, pp. 1-19).

In arguing his case, Burlington pointed out that the three African American employees had also used the word, but were not terminated. The employer responded, in part, that this comparison was not appropriate because in the other cases, the comments did not incite complaints from coworkers and negative publicity regarding the way that Burlington's comments had. To this assertion, the court replied:

This argument misses the point. Plaintiff contends that his coworkers' reaction and the negative publicity that resulted were all the product of racial discrimination that ultimately influenced management. The point of a comparator analysis is that when two employees of different races who act in a similar manner are treated differently, it permits the inference that the race of the employees accounts for the difference (Burlington v. News Corp., 2010, pp. 28-32). 
Significantly, the court addressed a key issue that had seemingly never before been decided by the federal courts: "can an employer be held liable under Title VII for enforcing or condoning the social norm that it is acceptable for African Americans to say " $\mathrm{n} * * * \mathrm{r}$ " but not whites?” In its analysis, the court began with the text of Title VII, which makes it unlawful to discriminate against any individual because of such individual's race (Burlington v. News Corp., 2010, pp. 39-41; 42 U.S.C. § 2000e-2(a)(1)). The court then pointed out that it "is well settled that Title VII's prohibition of race-based discrimination protects white employees as well as minority employees” (Burlington v. News Corp., 2010, pp. 39-41; McDonald v. Santa Fe Trail Transp. Co., 427 U.S. 273, 278-79, 96 S. Ct. 2574, 49 L. Ed. 2d 493 (1976)). The court then examined whether there is any justification for treating differently a white employee and an African American employee who both use the word. In its analysis, the court quoted Justice Holmes, who had observed that a "word is not a crystal, transparent and unchanged, it is the skin of a living thought and may vary greatly in color and content according to the circumstances and the time in which it is used." The court agreed that this was certainly so with this word. Indeed, explained the court, Merriam-Webster notes in the usage section of its definition of the word that "[i]ts use by and among blacks is not always intended or taken as offensive, but . . . it is otherwise a word expressive of racial hatred and bigotry" (Burlington $v$. News Corp., 2010, pp. 39-41, quoting Merriam Webster's Collegiate Dictionary 837 (11th ed. 2005); see McDonald, 1976). The court went on to say:

Historically, African Americans' use of the word has been ironic, satirical, or even affectionate. Too often, however, the word has been used by whites as a tool to belittle, oppress, or dehumanize African Americans. When viewed in its historical context, one can see how people in general, and African Americans in particular, might react differently when a white person uses the word than if an African American uses it (Burlington v. News Corp., 2010, pp. 39-41).

Nevertheless, the court was unable to conclude that this represented a justifiable reason for allowing the employer to draw race-based distinctions between employees. Importantly, the court elaborated:

It is no answer to say that we are interpreting Title VII in accord with prevailing social norms. Title VII was enacted to counter social norms that supported widespread discrimination against African Americans. See McDonnell Douglas, 411 U.S. at 800 (stating that the purpose of Title VII was "to eliminate those discriminatory practices and devices which have fostered racially stratified job environments to the disadvantage of minority citizens"). To conclude that the Station may act in accordance with the social norm that it is permissible for African Americans to use the word but not whites would require a determination that this is a "good" race-based social norm that justifies a departure from the text of Title VII. Neither the text of Title VII, the legislative history, nor the caselaw permits such a departure from Title VII's command that employers refrain from "discriminat[ing] against any individual . . . because of such 
individual's race." (Burlington v. News Corp., 2010, pp. 41, 42; 42 U.S.C. § 2000e-2(a)(1); see McDonnell Douglas, 1973, p. 800)

As such, the court found that the employer's inability to explain why Burlington and his African American co-workers were treated differently permitted the conclusion that a similarly situated African-American employee was treated more favorably than a white employee under similar circumstances. Finally, regarding the hostile work environment claim, the court found that the behavior set forth did not constitute behavior that was so severe or so pervasive that it gave rise to a claim for hostile work environment (Burlington v. News Corp., 2010, pp. 35-36).

\section{Code Words Compendium}

In this section, based on the preceding legal examinations, we have grouped together code words and code phrases which the courts and/or the Equal Employment Opportunity Commission have construed to be evidence of impermissible employment discrimination and/or harassment. This section also contains a sub-section of code words and phrases that the courts have ruled are legally permissible and thus do not raise any inference of discrimination and/or harassment (though the words and remarks may be ethically impermissible and immoral).

\section{A. Race and Color}

The following have been deemed to be legally impermissible race- and color-related code words and phrases:

1. Calling a co-worker a "white b**ch" (Smith v. Fairview Ridges Hospital, 2010, p. 16).

2. Referring to a co-worker in terms of "your kind" (Smith v. Fairview Ridges Hospital, 2010, p. 20).

3. Referring to black employees as "another one," "one of them," "poor people," "that one," and "all of you” (Abramson v. William Patterson College of New Jersey, 2001, p. 278; Aman v. Cort Furniture Rental Corporation, 1996, pp. 18-19).

4. Calling a black employee "Buckwheat" (Smith v. Fairview Ridges Hospital, 2010, p. 19).

5. References to "ghetto children" (were "perhaps racially inappropriate”) (Smith v. Fairview Ridges Hospital, 2010, p. 18).

6. References to "ghetto," "fried chicken," "runaway slaves," and "slave driver" (Smith v. Fairview Ridges Hospital, 2010, p. 19).

7. Manager telling supervisor: "So, you want to hire your own people" (Hagan v. City of New York, 2014, p. 489).

8. References to African-American employee as a "drug dealer" (McGinest v. GTE Service Corp., 2004, p. 1117).

9. Supervisor said to African-American employee "only drug dealers can afford nice gold chains” (McGinest v. GTE Service Corp., 2004, p. 1107).

10. Co-workers referring to male African-American employee as "Aunt Jemina," "mammy,” and "Biscuit” (McGinest v. GTE Service Corp., 2004, p. 1110). 
11. Supervisor calling African-American employee "stupid $\mathrm{n}^{* * *} \mathrm{r}$ " to his face (McGinest $v$. GTE Service Corp., 2004, p. 1115-16).

12. References to workers as "chocolate cupcake" and "basketball player" (EEOC, Press Release, 2011).

13. References to "hockey player" and "like you and me" for preferring whites as job applicants (EEOC, 2011, Disparate Treatment in Hiring, Testimony of Boehringer).

14. Retail managers saying they are looking for applicants with a "clean cut image" because "this is a sophisticated upscale location," and we need people with "soft skills" (EEOC, 2006, Compliance Manual, Example 4, Racial Stereotyping, p. 7).

15. Referring to an employee or job applicant as "sounding white" or possessing a "black accent” (EEOC, 2006, Compliance Manual, What is Race Discrimination, p. 4).

16. Comparing a black employee to a "gorilla” (EEOC, 2006, Compliance Manual, Racial Harassment, p. 19).

17. Co-worker telling African-American employee: "Watch your back, boy" (EEOC, 2006, Compliance Manual, Example 15, Sufficiently Severe Conduct, p. 19).

18. Telling an African-American library employee not to create a "ghetto corner" in the library (EEOC, 2006, Compliance Manual, Example 18, Sufficiently Severe or Pervasive Conduct, p. 20).

19. Telling a black female programmer "You're so articulate for a black person” and "I didn't know that Oprah could write code” (EEOC, 2006, Compliance Manual, Example 18, Sufficiently Severe or Pervasive Conduct, p. 20).

20. Co-worker calling an employee "DAN," which apparently according to the EEOC means “Dumb Ass N***r” (EEOC, 2015, E-Race, Significant Race/Color Cases).

21. Store manager referring to African-Americans as "you people," and interracial couples as “Oreos” or "Zebras” (EEOC, 2015, E-Race, Significant Race/Color Cases).

22. Manager referring to black employees as "homeboy” (EEOC, 2015, E-Race, Significant Race/Color Cases).

23. Co-worker repeatedly calling a black co-worker "Cornelius," which is a reference to the ape character in the movie, "Planet of the Apes" (EEOC, 2015, E-Race, Significant Race/Color Cases).

\section{B. National Origin}

The following have been deemed to be impermissible national origin-related code words and phrases:

1. Co-workers stating to Muslim employee of Egyptian descent that Arabs and Muslims "should not be in the United States," and "should leave” (Mujtaba \& Cavico, September 2011, p. 18 see also, Cavico \& Mujtaba, 2012; Cavico \& Mujtaba, 2011).

2. Co-workers telling an employee of Afghan descent that "Afghanistan needs to be bombed and wiped out” (Mujtaba \& Cavico, September 2011, p. 20 see also, Cavico \& Mujtaba, 2012; Cavico \& Mujtaba, 2011).

3. Managers calling employee an "Arab," even though he was from India (Equal Employment Opportunity Commission v. WC \& M Enterprises, Inc., 2007, pp. 397,400). 
4. Managers telling an employee, from India, that he should "just go back where you came from” and “This is America” (Equal Employment Opportunity Commission v. WC \& M Enterprises, Inc., 2007, pp. 397, 400).

5. Dean of college telling professor of Hungarian descent that he had a "heavy accent" and was not a "team player" Marosan v. Trocaire College, 2015, p. 57-58).

6. Saying that Puerto Rico is an "island filled with criminals" (EEOC, 2008, Digest of Equal Employment Opportunity Law, p. 6).

7. Denying a Native-American a promotion because a white candidate was a "better fit" (EEOC, 2006, Compliance Manual, Example 12, Discriminatory Selection Decision, p. 14).

8. In context of housing discrimination referring to housing applicants as "drug dealers" and creating "low cost, high crime neighborhoods" construed as code words for national origin discrimination against Hispanics (Avenue 6E Investments, LLC v. City of Yuma., 2016, pp. 29-30)

\section{Sex}

The following have been deemed to be legally impermissible sex-based code words:

1. Calling a co-worker a "b**ch" (Smith v. Fairview Ridges Hospital, 2010, p. 16).

2. References to "figure skater" for preferring white females as job applicants and references to "small hands" for preferring women in general as job applicants (EEOC, Press Release, 2011; EEOC, 2011, Disparate Treatment in Hiring, Written Testimony of Lopez-Rodriguez).

3. Saying a female job applicant was "not the type" for the position (EEOC, 2011, Disparate Treatment in Hiring, Written Testimony of Lopez-Rodriguez).

4. Telling a new female employee that she needed to learn how to "play with the boys" (EEOC, 2006, Compliance Manual, Race and Color Discrimination, Example 19, Sufficiently Severe or Pervasive Conduct, p. 21).

5. Transgender woman employee was told by supervisor "I'd hate to lose you" and "Don't rock the boat” (Patricia Dawson v. H\&H Electric, Inc., 2015, pp. 11-12).

6. Supervisor told lesbian employee that she "dressed more like a male than a female," her "demeanor" was a "little more mannish," she was not a good fit because of "the way she carried herself," and that she "used profanity, a lot of profanity, and she was loud" (Tracey Reed v. South Bend Nights, Inc., 2015, pp 9-10).

7. Male supervisor told terminated woman engineer that "women were not worth a shit" and they "should be at home, not working” (Malos, 2015, p. 271).

8. Female insurance specialist with four children denied a promotion was told by immediate supervisor that "you have kids" and "you have a lot on your plate right now" (Malos, 2015, p. 272).

\section{Religion}

The following have been deemed to be legally impermissible religion-related code words and phrases: 
1. Employer stated that she wanted "to get rid of all the Arabs" was sufficient evidence of an intent to discriminate based on national origin against Arab employee (Cavico \& Mujtaba, 2012, p. 101).

2. Continually calling employee, a native of Egypt and practicing Muslim, whose name was "Mamdouh,” by the “westernized” nickname "Manny” over employee’s objections (Cavico \& Mujtaba, 2012, p. 101, p. 101).

3. Comments that "Muslims do not belong in America" and "should be kicked out" were evidence that employee, Muslim of Indian descent, was fired due to his Islamic faith (Cavico \& Mujtaba, 2012, p. 103).

4. Comment by supervisor that Muslim employee was told to "go to Mecca to pray" was evidence of an intent to discriminate (Cavico \& Mujtaba, 2012, p. 104).

5. Co-workers stating to Muslim employee that she was a "symbol of 9/11 to customers" (Mujtaba \& Cavico, September 2011, p 14; see also, Cavico \& Mujtaba, 2012; Cavico \& Mujtaba, 2011).

6. Co-workers stating to Muslim employee that Muslims “do not belong in America” and they should "all be kicked out" (Mujtaba \& Cavico, September 2011, p. 15; see also, Cavico \& Mujtaba, 2012; Cavico \& Mujtaba, 2011).

7. Managers stating to Muslim employee that "This is not an Islamic country" (Equal Employment Opportunity Commission v. WC \& M Enterprises, Inc., 2007, pp. 397, 400).

8. Calling colleagues or employees "Muslim extremists," "extremists," "Taliban,” "terrorists," "towel-head,” and “crazy” (Equal Employment Opportunity Commission v. Sunbelt Rentals, 2008, p. 311; Equal Employment Opportunity Commission v. WC \& M Enterprises, Inc., 2007, p. 400).

9. Calling Muslim employees "towelhead," "raghead," and "rock thrower” (Mujtaba \& Cavico, September 2011, pp. 19, 21; see also, Cavico \& Mujtaba, 2012; Cavico \& Mujtaba, 2011).

10. Repeatedly telling a Muslim employee that "Israel is OK" (Mujtaba \& Cavico, September 2011, p. 19; see also, Cavico \& Mujtaba, 2012; Cavico \& Mujtaba, 2011).

11. Telling a Muslim employee: “You are a Holy man” (Mujtaba \& Cavico, September 2011, p. 20; see also, Cavico \& Mujtaba, 2012; Cavico \& Mujtaba, 2011).

12. Asking a Muslim employee: "Who is your prophet? Is it Muhammad or Ali”? (Mujtaba \& Cavico, September 2011, p. 20; see also, Cavico \& Mujtaba, 2012; Cavico \& Mujtaba, 2011).

13. The dean of a college telling a professor: "You are Orthodox" (Abramson v. William Patterson College of New Jersey, 2001, p. 278).

14. Co-workers telling a female Jewish employee that she lived in "Jewtown," "you people and your fur coats," and that she was "very vocal” (Baron v. W.W. Grainger, Inc., 1996, pp. 692-93).

\section{E. Age}

The following have been deemed to be impermissible age-related code words and phrases: 
1. Supervisor beginning sentences said to discharged employee "in your day and age..." (Tomassi v. Insignia Financial Group, Inc., 2007, p. 112).

2. Supervisor telling employee that she "should retire" so she could "take some time off to rest” (Tomassi v. Insignia Financial Group, Inc., 2007, p. 112).

3. Supervisor telling employee that she "could understand the mentality of" senior residents (Tomassi v. Insignia Financial Group, Inc., 2007, p. 112).

4. Employer wanted "sharp young people” (Aman v. Cort Furniture Rental Corporation, 1996, p. 21).

5. Employee told he was not a "forward enough thinker" (Aman v. Cort Furniture Rental Corporation, 1996, p. 21).

6. Employer saying that employee should "retire early" (Hagan v. City of New York, 2014, p. 500; Cavico \& Mujtaba, 2010).

7. Employer saying that the employee should "drop dead" (Hagan v. City of New York, 2014, p. 500; Cavico \& Mujtaba, 2010).

8. Employer saying to employee to "take off all that makeup" and "take off that wig" (Hagan v. City of New York, 2014, p. 500).

9. Employer saying that the employee is "too old to make tough decisions" (Cavico \& Mujtaba, 2010).

10. Employer saying: "We need young bloods around here” (Cavico \& Mujtaba, 2010).

11. Employer saying: "Let’s bring in the young guns" (Cavico \& Mujtaba, 2010).

12. Employer saying that employee "needs special treatment because she is getting old" (Cavico \& Mujtaba, 2010).

13. Restaurant chain saying it wants "young, fun, cute, and bubbly people” (Workplace, 2015, p. 24).

14. Restaurant chain denying employment to older applicants because they "wouldn't fit in” (Workplace, 2015, p. 24).

15. Restaurant chain saying it was looking for someone "young and perky" (Workplace, 2015, p. 24).

16. Employer saying to older worker that he or she was "overqualified" for position (Mujtaba \& Cavico, 2010).

17. Employer saying that the employee was "well suited to work with seniors" (Tomassi v. Insignia Financial Group, Inc., 2007, p. 116; Cavico \& Mujtaba, 2010).

18. Remarks by upper-level managers to older worker that indicated their preference for "youth over age," such as, not a "forward enough thinker," "sharp young people...are delivering a lot of work," and "older people that aren't delivering as much work" (Futrell v. J.I. Case, A Tenneco Company, 1994, p. 347).

19. Employer saying to older worker that he/she was unwilling or unable to "adapt" (Bienkowski v. American Airlines, Inc., 1988, p. 1507).

20. Older worker was terminated by supervisor after being told she "dressed like an old lady" and that company wanted "younger," "more vibrant" people with "more energy" (Malos, 2015, p. 272).

21. Older worker told he was not a "cultural fit" with the youthful orientation of the company and an "old fuddy-duddy” (Malos, 2015, p. 275). 
22. Older worker terminated because she was "not a good fit" with the new focus of the company and the changing needs of its clients (Malos, 2015, p. 276).

\section{F. Disability}

- Saying to a worker with a disability "when are you going to get better” (EEOC, 2008, Digest of Equal Employment Opportunity Law, p. 5).

\section{Legally Permissible Code Words}

The following code words and phrases were not deemed by the courts to be sufficient evidence to establish an initial case of legal discrimination and/or harassment based on the aforementioned protected categories:

1. Supervisor's remark that employee had a "Muslim issue" was regarded as a "stray remark" since it neither was made at the time of the employee's discharge nor did it refer to the discharge and thus was insufficient evidence to support an inference of discriminatory motive (Sekou Cherif v. Robert A. McDonald, 2015, p. 9).

2. Director of human resources saying to a Muslim employee that another employee should take medication if “Man, I'm hurting like a Muslim” (Mujtaba \& Cavico, 2013, p. 20).

3. Plant manager saying to Muslim employee that he wanted to have a "Come to Jesus meeting" with him to discuss performance and that he would take certain medication if “Man, I’m hurting like a Muslim” (Mujtaba \& Cavico, 2011, p. 30).

4. Supervisor saying to Muslim employee of Egypt descent that "Your religion is your problem” (Mujtaba \& Cavico, 2011, p. 31).

5. Co-worker referring to a black female employee as a "gal" (Smith v. Fairview Ridges Hospital, 2010, p. 9).

6. Coworkers referring to a black employee as being "from Walgreens" and the "new kid on the block" (Harrison v. Swedish Covenant Hospital, 1998, p. 6).

7. Coworkers referring to African-American employees as "stupid," "lazy," a "mother$\mathrm{f}^{* * * *} \mathrm{r}$, , a "b**ch," "and the like” (Allen v. Bake-Line Products, Inc., 2001, p. 28).

8. Supervisors calling a female African-American worker "assertive," "violent," and "insubordinate” (Cuttino v. Genesis Health Ventures, Inc., 2006, p. 16).

9. Supervisors calling a male employee "violent," "PTSD," "loose cannon," and "intimidating” (Santiago v. State of Connecticut, 2008, p. 17).

10. Supervisors and co-workers referring to black female employee as "aggressive," “agitated,” “angry,” "belligerent,” “disruptive,” "hands on hip,” "hostile,” "threatening," and "vituperative," as well as saying she was likened to the "Angry Black Woman Syndrome” (Humphries v. City University of New York, 2013, p. 29).

11. Supervisor calling African-American employee "lazy, shiftless, and incompetent," “ignorant," “inarticulate,” and “entitled” (Lloyd v. Hon. Eric H. Holder, Jr., 2013, pp. 28-29).

12. Supervisor saying to gay male employee that "Cupcake was right" about how to correctly fill out a form (Roger Isaacs v. Felder Services, LLC, 2015, pp. 5, 8). 
13. Supervisor's comment referencing "old timers" was not sufficient evidence of age discrimination because of the ambivalent manner in which it was made (Nidds $v$. Schindler Elevator Corp., 1996, pp. 918-19).

14. Comment that "we don't necessarily like grey hair" was found insufficient to establish inference of discriminatory motive because it was uttered in an ambivalent manner and was not tied directly to the employee's termination (Nesbit v. Pepsico, Inc., 1993, p. 705).

15. In context of school racial hostile environment claim, teacher calling a student "a gabber" not an impermissible code word because "the word 'gabber' in everyday parlance means "talkative" and "there is no support in the record for the assertion that the use of the term 'gabber' was racially motivated” (and "'gabber' is not akin to "uppity", which latter term could raise an inference of racism (Bridges $v$. Scranton School District, 2016, pp. 16-17).

Overall, the authors' purpose in providing the aforementioned list of code words was to provide some guidance to employers and managers, especially when training employees, as to what the courts have deemed to be legally impermissible and permissible code words. However, regarding the latter category, it must be pointed out, as courts have emphasized, that words, remarks, and terms which are "facially non-discriminatory" could in combination with other concrete factual allegations support a claim of discrimination (Humphries v. City University of New York, 2013, p. 29; Lloyd v. Hon. Eric H. Holder, Jr., 2013, pp. 28-29).

\section{Consequences for Management}

Code words and phrases and stereotypical remarks clearly can be grounds for a Title VII, ADEA, or ADA civil rights discrimination lawsuit. Discriminatory intent, motive, and animus, as well as harassment and hostility, can be derived from degrading and disrespectful words, terms, and phrases as well "stereotyped remarks" (Santiago v. State of Connecticut, 2008, p. 17). Yet determining what are sufficiently impermissible code words and phrases as evidencing discriminatory intent is a difficult challenge indeed. The intent to discriminate deduced from code works in certain cases is not that covert; rather, the words amount to a "smoking gun" statement of a discriminatory animus. Other words and remarks, however, are more vague, amorphous, and subjective, and thus truly covert, for example, the phrase "lack of fit" (Malos, 2015, p. 278). This challenge to differentiate "good" from "bad" words was underscored by the Court of Appeals for the Third Circuit in Aman v. Cort Furniture Rental Corporation (1996, pp. 1081-82): "Discrimination continues to pollute the social and economic mainstream of American life, and is often masked in more subtle forms. It has been easier to coat various forms of discrimination with the appearance of propriety, or to ascribe some other less odious intention to what is in reality discriminatory behavior. In other words, while discriminatory conduct persists, violators have learned not to leave the proverbial 'smoking gun' behind." Accordingly, the Court of Appeals for the Eighth Circuit in Smith v. Fairview Ridges Hospital (2010) offers some advice as to how to conduct an appropriate analysis of code word situations. First, the court notes that there are no "talismanic" words or expressions to sustain a discrimination or harassment claim. However, there may be "racially charged 'code words"” 
that can provide evidence of discriminatory intent by sending a "clear message" and carrying the "distinct tone" of discriminatory motivation and implications (Smith v. Fairview Ridges Hospital, 2010, p. 19; see also, Santiago v. State of Connecticut, 2008, p. 17). Regarding discrimination based on sex, code words can indicate that a person was discriminated against because he or she "did not conform to traditional gender stereotypes in terms of... appearance, behavior or mannerisms at work" (Tracey Reed v. South Bend Nights, Inc., 2015, p. 10).

Nevertheless, not all language with race or color-, sex-, national origin-, or religious connotations is automatically equivalent to discrimination or harassment. As such, there are words, remarks, comments, phrases that are "merely part of casual conversation, are accidental, or are sporadic do not trigger Title VII sanctions" (Smith v. Fairview Ridges Hospital, 2010, p. 21); and similarly, there will be no liability if the words complained of are "merely rude or unpleasant" (Smith v. Fairview Ridges Hospital, 2010, p. 22). Another factor in determining liability is whether the words were stated by co-workers or a supervisor, with the latter expression having more serious import (Smith v. Fairview Ridges Hospital, 2010, p. 22).

Yet, it is important for managers to be aware that the lack of offensiveness of code words or phrases does not mean that they cannot be evidence of impermissible discriminatory intent. As one court emphasized, "the touchstone inquiry remains whether circumstances permit a reasonable inference of discrimination” (Patricia Dawson v. H\&H Electric, Inc., 2015, p. 11) (emphasis in original). The "classic" example is the employer telling an older worker that he or she was not hired because he or she was "overqualified” (Mujtaba \& Cavico, 2010). Another example is the phrase that an employee was "well suited to work with seniors," which was not offensive per se, but was deemed by the courts to be adequate evidence of a supervisor's discriminatory intent in discharging the employee (Tomassi v. Insignia Financial Group, Inc., 2007, p. 116; Mujtaba \& Cavico, 2010). Similarly, telling an older worker that she "could understand the mentality of" the senior residents of a housing facility was not necessarily offensive but was inferential evidence of age discrimination (Tomassi v. Insignia Financial Group, Inc., 2007, pp. 112, 115). Furthermore, continually calling a Muslim employee of Egyptian descent by the Westernized “nickname" "Manny," despite frequent objections by the employee, was deemed to be sufficient evidence of an intent to discriminate, even though the name "Manny" is not a racial or religious slur or epithet (Mujtaba \& Cavico, 2013, p. 12). Since code word liability pursuant to civil rights laws is a difficult and challenging area of the law as well as one without much in the way of legal guidance, the prudent as well as ethical employer should strive to establish a workplace free of all bias, discrimination, and stereotyping. A prime way to create such a legal and ethical workplace is for the employer to engage in diversity education and training as well as to conduct diversity audits.

\section{Diversity Audits and Training}

In order to achieve a workplace free from fear, ignorance, bias, and stereotypes, the authors emphasize the importance of diversity audits and diversity training based on what is needed most to create a competitive advantage through the company's human resources. All managers and human resources professionals have a responsibility of creating an inclusive workplace for everyone by regularly auditing their firms on various diversity dimensions (Syed \& Ozbilgin, 2015). Managers must create a workplace that accommodates people of all backgrounds and 
abilities, so long as they can perform the job (Mujtaba, 2010). Today, there are many organizations that do an excellent job of diversifying their workforce in order to create an inclusive and respectful work environment for all.

An inclusive work culture displays the excellent ability of hiring diverse employees as well as attaining a balanced distribution of diverse staff in all departments. Furthermore, such an environment encourages success based upon individual effort and team performance and not premised on the mere "personal" preferences of managers, coworkers, clients, and/or customers, which preferences could be rooted in impermissible biases and stereotypes. Accordingly, it is recommended that each department manager should conduct an organizational diversity audit on an annual basis and set developmental goals for the coming year in order create and/or maintain an inclusive work culture for all employees represented in the modern and diverse workforce.

Diversity audits are becoming an essential element of understanding where the organization stands and how they can effectively get to their ideal destination (Mujtaba, 2014). Diversity audits represent the distance managers and leaders should cover in order to respect diversity goals within their organization. An audit is conducted to identify the baseline of a situation or evaluate the current situation within the organization with leading respect aimed towards a particular or certain area. To plan and implement a diversity audit is an imperative process for gaining and maintaining a competitive advantage through the human resources diversity (Dressler, 2012; Mujtaba, 2010). Usually, an audit would cover surveying, engaging or observing all groups of employees and as many human resource processes of the organization as possible. Furthermore, audits tend to rely on published literature and relevant available data to draw appropriate conclusion and recommendations. In order to provide this "edge” in the modern workplace, organizations should regularly monitor and audit the diversity make-up of their workforce (Mujtaba, 2010).

Dressler (2012) states that an audit is basically an analysis by which an organization measures where it currently stands and determines what it has to accomplish to improve its HR function. One important element of an audit would deal with the organization's culture and workforce communication to make sure it represents the unique qualities of the company, its founders and their overall values. Assessing the overt and covert use of certain code words within the company should be monitored to make sure there are no discriminatory or unfair employment remarks or practices resulting from them toward any of the employees, especially those who fall in the protected categories. Malos (2015) similarly emphasizes that staffing decisions must be scrutinized to make sure they are not made in a biased or "stereotypic" manner and that individuals are appraised based on job-related skills, knowledge, and capabilities and "valid performance metrics" (p. 278).

During the whole process of conducting a diversity audit within the organization it is important to be open, fair, and to have an effective communication plan. Building a communication channel before, during, and after the audit is important for finding qualitative and quantitative results for the audit. An auditor should effectively create an open and clear channel of communication about participation when starting the audit. It is crucial to let employees within the organization know that whatever they share with the auditor about the organization or company is kept within confidentiality boundaries between the auditor and the 
employee (Oberoi, 2013). The auditor should focus on building a bond of trust with the employees so that the information gathered and recorded will not be held against them in anyway and that the process will be conducted in a professional manner. The goal is to create a legal, ethical, diverse, and effective workplace.

\section{Conclusion}

Discriminatory intent can be explicit, direct, obvious, as well as flagrant. However, it is often difficult to ascertain a discriminatory animus since discrimination can also be masked in more subtle and covert forms. Certain code words and phrases examined herein leave no question as to discriminatory intent but others are of the more subtle and covert category. Nonetheless, these covert code words can be used by the courts and juries to infer discriminatory intent. Code words, therefore, become highly relevant in discrimination as well as harassment cases for what they do reveal - the intent of the speaker. The courts and EEOC have provided scant guidance as to code word liability. Nonetheless, the case law clearly indicates that code words can show intent; and intent if discriminatory and biased can lead to liability for the employer pursuant to U.S. civil rights laws. Thus, it is incumbent on the employer to create a workplace free from discrimination, harassment, bias, and stereotyping; and a principal way to achieve such a legal and ethical workplace is for the employer to provide diversity education and training as well as to conduct diversity audits on a regular basis.

\section{References}

Abramson v. William Patterson College of New Jersey, 260 F.3d 265 (Court of Appeals for the Third Circuit 2001).

Allen, Jr. v. Bake-Line Products, Inc., 2001 U.S. Dist. LEXIS 17103 (District Court for the Northern District of Illinois 2001).

Aman v. Cort Furniture Rental Corporation, 85 F.3d 1074 (Court of Appeals for the Third Circuit 1996).

Ash v. Tyson Foods, Inc., 546 U.S. 454 (Supreme Court of the United States 2006).

Avenue 6E Investments, LLC v. City of Yuma, 2016 U.S. App. LEXIS 5601 (Court of Appeals for the Ninth Circuit 2016).

Baron v. W.W. Grainger, Inc., 944. F. Supp. 689 (District Court for the Northern District of Illinois 1996).

Bienkowski v. American Airlines, Inc., 851 F.2d 1503 (Fifth Circuit Court of Appeals 1988).

Bridges v. Scranton School District, 2016 U.S. App. LEXIS 4667 (Court of Appeals for the Third Circuit 2016).

Burlington v. News Corp., 759 F. Supp. 2d 580 (Eastern District of Pennsylvania. 2010).

Cavico, F. J., Mujtaba, B. G., \& Samuel, M. (May 2, 2016). Code words and covert employment discrimination: Legal analysis and consequences for management. Paper presented at the $3^{\text {rd }}$ International Conference on New Challenges in Management and Business: Organization and Leadership. Dubai, United Arab Emirates (UAE). Website: www.NCMConferences.com

Cavico, F. J., \& Mujtaba, B. G. (2012). Discriminatory practices against Muslims in the American workplace. Journal of Leadership, Accountability, \& Ethics, 9(1), 98-117.

Cavico, F. J., \& Mujtaba, B. G. (2011). Employment discrimination and Muslims in America. Journal for Global Business Advancement, 4(3), 279-297.

Cavico, F. J., \& Mujtaba, B. G. (2014). Legal challenges for the global manager and entrepreneur (2 ${ }^{\text {nd }}$ ed.). Dubuque, Iowa: Kendall Hunt Publishing Company.

Cuttino v. Genesis Health Ventures, Inc., 2006 U.S. Dist. LEXIS 1342 (District Court for the District of Connecticut 2006).

Dressler, G. (2012). Fundamentals of Human Resources Management ( $2^{\text {nd }}$ edition). New York: Prentice Hall.

Equal Employment Opportunity Commission (2015). Age Discrimination. Retrieved October 6, 2015 from: http://www1.eeoc.gov//laws/types/age.cfm.

Equal Employment Opportunity Commission (2015). Disability Discrimination. Retrieved October 6, 2015 from: http://www1.eeoc.gov//laws/types/disability.cfm. 
Equal Employment Opportunity Commission http://www1.eeoc.gov//laws/types/harassment.cfm.

(2015). Harassment. Retrieved October 6, 2015 from:

Equal Employment Opportunity Commission (2015). National Origin Discrimination. Retrieved October 6, 2015 from: http://www1.eeoc.gov//laws/types/nationalorigin.cfm.

Equal Employment Opportunity Commission (2015). Prohibited Employment Policies/Practices. Retrieved October 6, 2015 from: http://www1.eeoc.gov//laws/practices/index.cfm.

Equal Employment Opportunity Commission (2015). Race/Color Discrimination. Retrieved October 6, 2015 from: http://www1.eeoc.gov//laws/types/race_color.cfm.

Equal Employment Opportunity Commission (2015). Religious Discrimination. Retrieved October 6, 2015 from: http://www1.eeoc.gov//laws/religion.cfm.

Equal Employment Opportunity Commission (2015). Sex-Based Discrimination. Retrieved October 6, 2015 from: http://www1.eeoc.gov//laws/types/sex.cfm.

Equal Employment Opportunity Commission (2006). EEOC Compliance Manual, Section 15: Race and Color Discrimination. Retrieved September 23, 2015 from: http://www.eeoc.gov/policy/docs/race-color.html.

Equal Employment Opportunity Commission (2015). E-Race: Significant EEOC Race/Color Cases. Retrieved September 23, 2015 from: http://www.eeoc.gov/eeoc/initiatives/e-race/caselistcfm.

Equal Employment Opportunity Commission (2006). Digest of Equal Employment Opportunity Law, Volume XVII, No. 2. Retrieved September 23, 2015 from: http://www1.eeoc.gov//federal/digest/xvii-2.cfm.

Equal Employment Opportunity Commission (Meeting of June 22, 2011). Disparate Treatment in Hiring. Written Testimony of Boehringer. Retrieved September 23, 2015 from: http://www1.eeoc.gov/eeoc/meetings/6-22-11/boehringer.cfm.

Equal Employment Opportunity Commission (Meeting of June 22, 2011). Disparate Treatment in Hiring. Written Testimony of Lopez-Rodriquez. Retrieved September 23, 2015 from: http://www1.eeoc.gov/eeoc/meetings/6-22-11/lopez.cfm.

Equal Employment Opportunity Commission (June 22, 2011). Press Release: Disparate Treatment in Hiring Remains Major Problem, Experts Tell EEOC. Retrieved September 23, 2015 from: http://www1eeoc.gov//eeoc/newsroom/release/6-2211a.cfm.

Equal Employment Opportunity Commission (October 1, 2012). Press Release: EEOC Sues AmerisourceBergen Corporation for Age Discrimination. Retrieved September 23, 2015 from: http://www1.eeoc.gov//eeoc/newsroom/release/10-1-12b.cfm.

Equal Employment Opportunity Commission v. Sunbelt Rentals, Inc., 521 F.3d 306 (Court of Appeals for the Fourth Circuit 2008).

Equal Employment Opportunity Commission v. WC\&M Enterprises, Inc., 496 F3d 393 (Court of Appeals for the Fifth Circuit 2007).

Futrell v. J.I. Case, A Tenneco Company, 38 F.3d 342 (United States Court of Appeals for the Seventh Circuit 1994).

Hagan v. City of New York, 39 F. Supp. 3d 481 (District Court for the Southern District of New York 2014).

Harrison v. Swedish Covenant Hospital, 1998 U.S. Dist. LEXIS 15957 (District Court for the Northern District of Illinois 1998).

Humphries v. City University of New York, 2013 U.S. Dist. LEXIS 169086 (District Court for the Southern District of New York 2013).

Lloyd v. Hon. Eric H. Holder, Jr., 2013 U.S. Dist. LEXIS 178456 (District Court for the Southern District of New York 2013).

Malos, S. (2015).Overt Stereotypes Biases and Discrimination in the Workplace: Why Haven’t We Fixed This by Now. Employee Responsibilities and Rights Journal, Vol. 27, No. 4, pp. 271-280.

Marosan v. Trocaire College, 2015 U.S. Dist. LEXIS 43082 (District Court for the Western District of New York 2015).

McGinest v. GTE Service Corp., 360 F.3d 1103 (Court of Appeals for the Ninth Circuit 2004).

McDonald v. Santa Fe Trail Transp. Co., 427 U.S. 273, 278-79; 96 S. Ct. 2574; 49 L. Ed. 2d 493 (1976).

McDonnell Douglas, 411 U.S. 792 (1973).

Merriam Webster's Collegiate Dictionary 837 (11th ed. 2005).

Mujtaba, B. G. (2014). Managerial skills and practices for global leadership. ILEAD Academy: Florida.

Mujtaba, B. G. (2010). Workforce Diversity Management: Challenges, Competencies and Strategies (2 ${ }^{\text {nd }}$ edition). ILEAD Academy: Florida. 
Mujtaba, B. G., \& Cavico, F. J. (2011). A legal review of stereotypes, biases, and discrimination against Muslim-American Employees. International Journal of Management Research \& Emerging Sciences, 1(1), 21-36.

Mujtaba, B.G., \& Cavico, F. J. (2011). Reasonable accommodation dilemmas for Muslim-American employees’ religious beliefs, observances, and practices. Proficient: An International Journal of Management, 3(9), 7-33.

Mujtaba, B. G., \& Cavico, F. J. (2010). The aging workforce: Challenges and opportunities for human resource professionals. Davie, Florida: ILEAD Academy, LLC.

Nidds v. Schindler Elevator Corp., 113 F.3d 912 (Court of Appeals for the 9th Circuit 1996).

Nesbit v. Pepsico, Inc., 994 F.2d 703, 705 (Court of Appeals for the 9th Circuit 1993).

Oberoi, S. (2013). How do you conduct a diversity audit and survey? Retrieved from http://www.shrm.org/india/hrbuzz/blogs/shrm-india/pages/how\%20do\%20you\%20conduct\%20a\%20diversity\%20audit\%20and\%20survey_.aspx

Patricia Dawson v. H\&H Electric, Inc., 2015 U.S. Dist. LEXIS 122723 (District Court for the Eastern District of Arkansas 2015).

Roger Isaacs v. Felder Services, LLC, 2015 U.S Dist. LEXIS 146623 (District Court for the Middle District of Alabama 2015).

Santiago v. State of Connecticut, 2008 U.S. Dist. LEXIS 76026 (District Court for the District of Connecticut 2008).

Sekou Cherif v. Robert A. McDonald, 2015 U.S. App. LEXIS 11309 (Court of Appeals for the Seventh Circuit 2015).

Smith v. Fairview Ridges Hospital, 2010 U.S. App. LEXIS 22114, 625 F.3d 1076 (Court of Appeals for the Eighth Circuit 2010); certiorari denied, 131 S. Ct. 2904 (U.S. Supreme Court 2011).

Syed, J., \& Ozbilgin, M. (2015). Managing diversity and inclusion: An international perspective (edited). Los Angeles: SAGE.

Taggart v. Time, Inc., 924 F.2d 43 (Court of Appeals for the Second Circuit 1991).

Tomasssi v. Insignia Financial Group, Inc., 478 F.3d 111 (Court of Appeals for the Second Circuit 2007).

Tracey Reed v. South Bend Nights, Inc., 2015 U.S. Dist. LEXIS 170459 (District Court for the Eastern District of Michigan 2015).

Workplace (September 28 - October 4, 2015). No Place for Old Waiters at Texas Roadhouse? Bloomberg Business Week, pp. 23-24. 